\title{
Lean Production Practices to Enhance Organisational Performance
}

\author{
Satya Shah ${ }^{1, a}$, Elmira Naghi Ganji1 and Alec Coutroubis ${ }^{1}$ \\ ${ }^{1}$ Faculty of Engineering and Science, University of Greenwich, UK
}

\begin{abstract}
Service sector organisations are constantly overcoming the challenges facing the overproduction and waste reduction within their environments. Industries are also becoming very competitive thus forcing them to seek suitable production organisation strategies with the aim towards enhancing their competitiveness and efficiency. The aim of this research study is to investigate the impact of lean production practices on the performance of service based businesses through the case study of a local baked goods supplier. The research framework adopted consists of questionnaire survey method implemented with different end users, thus covering the overall production - retail customer cycle. The research results and analysis justify the objective of the research that lean production practices enhance the performance of the supplier company and the common tool identified were JIT (Just in Time), Value Steam Mapping (VSP) and the 5S methods. The results also suggest that JIT method has a higher impact towards improvement on performance relating to quality, speed, dependability, flexibility and cost of the supplier. However, the research study also identifies that one of the major challenges faced by the organisation while adopting lean practices was the lack of commitment from top management, continuous training and employee engagement measures.
\end{abstract}

\section{Introduction}

The current manufacturing and production based environments are facing the key challenges towards managing and reducing over production and towards the reduction and elimination of waste within their environments. Industries are also becoming very competitive thus forcing them to seek suitable production organisation strategies with the intention of enhancing their competitiveness and efficiency. The adoption of lean production is an edge for industry to manage their operational and strategic gains thus reducing waste. Early research within this aspect suggests in order to achieve continuing competitive advantage, industries need to create appropriate production systems and technologies mainly relating to high product quality, reducing product design time, demand based production and reduction of waste and inventory management [1].

Lean production is a concept which may be viewed and implemented at a number of levels and also a commitment process of persistent improvement that can significantly impact upon an organisation's well-being, wealth and competitiveness [2]. Global competition has increased pressures on manufacturing plants towards improving different factors of operational performance. According to [3], it was deduced that organisations make use of broad production practice, and this is challenging because they are unable to improve and increase their production or even satisfy their customers. Nevertheless, for some organisation using current technologies such as Lean production practice is now becoming a critical and regular practice to achieve better performance attainments [4]. Lean organisations have the ability of producing great quality products cautiously, in lesser volumes, as well as conveying them to market quicker than mass producers. Lean management is simply all about operating the most proficient as well as effective organisation possible, with a minimal cost and zero waste and still meeting customers demand. Effective and fruitful lean producers have come to know that lean production practice is a corporate vision that helps everyone from design to product management as well as marketing and outside the four walls to involve outside suppliers and trading partners. With the correct procedure, policy and backup tools, lean organisations can access the live and up to date data that their decision makers need to attain corporate goals, together with minimizing inventory and waste, shortening lead times also producing to demand.

Currently, many service industries are faced with the problem of increasing the product quality. Considering the challenges of present competition, both locally and globally, many organisations are now improving the quality of their products, decreasing cost and meeting the unexpected need of their customers. With this focus, this study is focussed to identify the extent of Lean production practices adoption in organisations. It seeks to provide a more comprehensive knowledge about the impact of lean production practices on organisations' performance and finally, the challenges they face in the implementation of lean production practices on organisations.

\footnotetext{
${ }^{a}$ Corresponding author: s.shah@gre.ac.uk
} 


\section{Literature Review}

This literature review aims to develop a better understanding of the concepts that seem to play a vital role in organisation's performance. Current literatures will provide relevant materials related to the specific research objectives. The review will be split into several sections and will be structured as follows; an overview of lean production, its goal and strategy, its principles and tools, seven deadly waste, benefits of adopting lean production and the barriers of implementing lean production. The study will provide a framework towards the relationship between lean production practice and organisations performance.

\subsection{Lean Production}

Lean production is a mixture of both mass production and craft production. According to earlier research "the machine that changed the world", the word Lean production was used contrary to the mass production system [5]. Toyota concentrated on applying the Lean production principles by using simple technologies and lower prices automation at the expense of computer technology. Lean production was founded by TPS $[5,6]$. TPS focused on eliminating waste or non-value added activities, bearing in mind the entire production process and using different tools and technique to reduce the waste for example; JIT, VSM, 5S, Kanban (pull) systems, Kaizen, synchronous manufacturing, Pokayoke [3, 5], which led to the reduction of stocks and finishing time, thus increasing their delivery performance, balancing the use of space, bettering the use of resources and improving their productivity and quality [7].

Studies define Lean production as a philosophy or strategy which depends on a set of practices used to reduce waste with the intention of improving the performance of enterprises [5]. Today, Lean production has been adopted across the world by lots of major companies to stay competitive in the global market [8]. Ever since Lean production was first used, many authors have tried to describe Lean theoretically $[9,10,11]$; however, their descriptions were unclear and this led to a communication problem [12], implementation problem (in enterprises) and the problem of creating objectives that are specific [13]. The study carried out by [14] shows that since there is different theoretical approach about Lean production, identifying the use of its actual benefits becomes difficult. This implies that since there is lack of clear description, if there is need to establish it within a company will be difficult or even not in accord with Lean Production principles, thus leading to a hard evaluation of the effectiveness of the concept. Hence, it is essential for Lean production success to be estimated before it is implemented so as to avoid money and time wastage [15]. Existing research has investigated Lean production definition, goals, and approaches that are associated with the concept. In his research he categorized Lean into four different ways, namely:

1. Lean as a process of continuous effort or change or "becoming lean",

2. Lean as a process of "becoming lean",
3. Lean as a philosophy of "lean thinking" or "the Toyota way" and

4. Lean as a fixed state or "being lean [15].

The key principles behind Lean production includes specify value; identify value stream, flow, pull and perfection [1]. Hence, for continuous improvement within the organisation, organisations need to use these principles because it will help them in improving their operation.

\subsection{Lean and Service Industries}

Presently, the service industry is trying to improve its performance by embracing the continuous improvement process so as to stay competitive and satisfy their customers. Hence for them to achieve this there is a need for this service industry to adopt the Lean production practice as a full business strategy. Below are the deadly wastes that affect service industry. The main aim of Lean production is to eliminate all type of waste within the production process. Waste includes all activities that do not add value to organisations or customer. It is any activity that customers will not pay for; thus it is important for organisations to identify the concept of this waste and reduce it. Earlier research by Taiicho Ohno design of seven wastes or "Muda" which form the core of "lean philosophy" that is faced by companies on how to identify and reduce them.

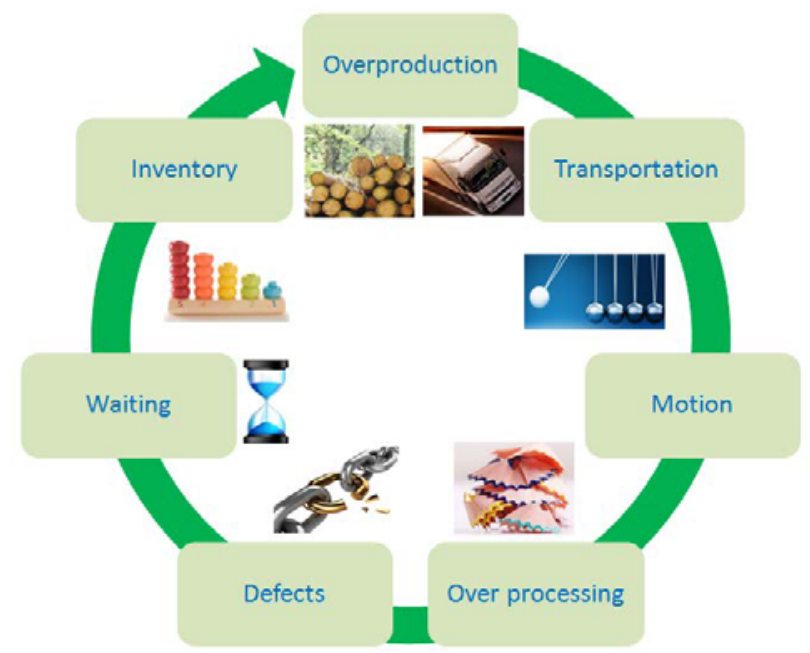

Fig. 1. The Seven Deadly Wastes of Lean Philosophy.

- Overproduction - Overproduction is believed to be the most dangerous among the seven wastes that were identified by Ohno;

- Transportation - The waste for transportation of goods between the supply chain;

- Unnecessary Motion - This involves the movement of workers in form of bending, reaching, stretching, walking in a distance that is very long in order to get a material, too or information or even moving to see better.

- Unnecessary Inventory - This is referred to as having excess raw materials or components, semi or finished goods that are not processed; hence making businesses to need additional storage area.

- Waiting - Waiting take place whenever time is not managed or used well. It is when the equipment, 
material, customers or workers are not moving, working or not adding value to production process.

- Over or inappropriate processing - Over processing is referred to as taking unnecessary steps that are not required (beyond customers specification) in a production process.

- Defect - Defects is referred to as producing products that are faulty or imperfect thus leading to inspection, rework and fixing.

\subsection{Lean Practices on Organisational Performance}

Lean production has been developed and adopted by companies that wish to improve their performance globally and locally. However, in evaluating its impact on organisations performance, several authors tried this into "leanness". Hence, in this context, [16], used the model to measuring the degree of leanness in UK agricultural machining sector while another study established a model that help in determining the level of leanness by using different attributes of lean such as Kaizen, JIT and quality [17]. Another research helped in examining the impact of exact influences leanness have on manufacturing system [18]. From their study, it was seen that the component which are mostly vital to leanness consist of imperfections, cost, lead time and value. Lastly, research established a model which also helped measuring the level of leanness. The study was based on 30 criteria and fuzzy logic approach was used during the study. This implies that leanness is connected to organisations performance [19].

Due to the fact that the benefits of lean approaches are difficult to measure, an IT based system called balanced scorecard system supports the change strategies and would help managers to focus on the linkages and operational efficiencies within their organisations [20]. Probably the total life cycle time would be the most effective gauge to measure the lean progress, hence, the scorecard approach could be a good practice in this case, whereas it is evident that more than $60 \%$ of all the firms are using scorecard [21]. It could be mentioned that the scorecard would not be the best approach to define the best strategies towards going lean and hence, it is the manager's duty to handle the measurement considerations especially with the aid of the advanced software programmes.

\subsection{Lean Production in Food and Beverage Industries}

Presently, the food and beverage industry are faced with the challenge of not identifying waste and meeting up their market price (profit). Although, they wish to improve their productivity and take competitive advantage of the market globally. Hence, with Lean production, the food and beverage industry will be able to identify and eliminate waste through continuous improvement. Lean Production practice for food and beverage industries are altered copied from manufacturing industries. According to studies, many of these tools and technique have been used to improve the performance of organisation [22]. As shown below some of the widely used Lean production tools and how they can be used by the Company X (baked goods suppliers) to improve their quality, speed, dependability, flexibility and cost.

Table 1. Summary of Lean Production Tools.

\begin{tabular}{|c|c|c|}
\hline Tool & Description & Reference \\
\hline $\begin{array}{c}\text { Value } \\
\text { Stream } \\
\text { Mapping }\end{array}$ & $\begin{array}{l}\text { VSM is a tool used in } \\
\text { designing, analysing or } \\
\text { mapping out all actions } \\
\text { (both value and non-value) } \\
\text { in the production process by } \\
\text { examining the flow of raw } \\
\text { material from its supplier to } \\
\text { end customers. Research } \\
\text { studies suggest by using } \\
\text { VSM, organisation can } \\
\text { decrease their lead-time and } \\
\text { production time, smoothing } \\
\text { their production, decrease } \\
\text { waste and improve the } \\
\text { quality of a product. It } \\
\text { reduce operational cost, } \\
\text { increase flexibility and helps } \\
\text { organisations to meet the } \\
\text { demand of their customers. }\end{array}$ & [23] \\
\hline$J I T$ & $\begin{array}{l}\text { A process which states that } \\
\text { an organisation should } \\
\text { produce the right product at } \\
\text { the right time. Research } \\
\text { studies also state that by } \\
\text { using JIT, organisation will } \\
\text { reduce production cost, } \\
\text { inventory, changeover time, } \\
\text { set up time and likely waste. }\end{array}$ & [24] \\
\hline Pokayoke & $\begin{array}{l}\text { This is referred to a tool } \\
\text { which helps staff to avoid } \\
\text { errors. The purpose of } \\
\text { Pokayoke is to eliminate } \\
\text { product defects by } \\
\text { preventing, correcting or } \\
\text { drawing attention to human } \\
\text { errors. The Lean concept is } \\
\text { criticized in the literature } \\
\text { from the perspective of the } \\
\text { personnel, because this side } \\
\text { is less known, focusing } \\
\text { primarily on techniques for } \\
\text { improving the performance } \\
\text { of the system. }\end{array}$ & {$[25]$} \\
\hline Kanban & $\begin{array}{l}\text { Kanban is stock controlling } \\
\text { system which is achieved } \\
\text { with FIFO method. An } \\
\text { effective tool that } \\
\text { contributes the functioning } \\
\text { of the whole production } \\
\text { process. According to } \\
\text { Kanban system has many } \\
\text { advantages over computer } \\
\text { technologies, such as; } \\
\text { reduced cost of information } \\
\text { processing, it is easy to } \\
\text { obtain and transmit } \\
\text { information in a dynamic } \\
\text { environment; the demand } \\
\text { for materials is judiciously } \\
\text { sized. }\end{array}$ & {$[26]$} \\
\hline
\end{tabular}




\section{Research Methodology}

A combination of research methods and approaches has been employed within this research. This included the use of critical literature review analysis, case study based method investigating in a local baked goods supplier and through personal interviews on the service company delivering the baked goods products to customers. The literature review conducted extensively at the initial stages of the research identified the research gaps in knowledge within this area.

\subsection{Research Approach and Strategy}

Methodology deals with the basic principal question of how to collect analyse and interpret data in a structured manner. The research started from theory and then moved into data, collecting qualitative information from case studies by using questionnaires and interview. The variable for this study was generated from the literature and the relationship to each other is seen within the framework. The deductive approach also includes a qualitative research method that is used to gain more insight. There is numerous research strategies used for attaining answers in any research objectives. However, due to the nature and objective of this study, the questionnaire was designed to clarify the assumption gained from the literature. The target population was chosen based on the scope of this research study. Because of this, only local baked goods supplier (Company X) were considered as possible respondents. Also interview questions were structured for the managers of a local university cafe while another questionnaire aimed at university students. According to methods, the correct sample choice and methods are important factors for collecting valid and measurable data for any research [27].

\subsection{Data Collection Technique}

Research states that an appropriate data collection method contributes to the success of research studies. In business research, the primary and secondary data are used to collect the necessary data. Both sources of data are used to achieve efficiency and effective research objectives. The secondary data provides an ability to save time and money, therefore it has to be analysed first before the collection of the new material [28]. The primary data have to be collected as well, as the secondary data may not always provide the needed answers to all research questions. In order to reach the research objective, the primary and secondary data were used in this study.

However, after careful consideration of the various options for data collection, author decided that two type of data collection modes been quantitative and qualitative (interview and questionnaire respectively) would be used as earlier stated. Hence, 3 steps were used to get the data for the study. Firstly, questionnaire was given to local university students (customers). This helped the researchers to find out content such as "how satisfied customers are on the product sold on campus etc." Secondly, an interview with the cafe managers was carried out to help understand the pattern of business such as which their suppliers are, and how often they order from their suppliers etc. Finally, questionnaire was given to local baked goods suppliers which are the main process of data collection.

\subsection{Questionnaire Design}

After the decision had been made to use the questionnaire and interview to collect data, the next step was to plan and design a suitable questionnaire. With the aim of producing a reliable questionnaire and minimising biases in this research, the author considered issues such as wording, appearance and appropriate categorisation of the variable in the questionnaire. The design of the questionnaire requires a good understanding of the subject matter. With an insight to the literature review conducted, the survey questions were based on the research framework. Another factor considered was the sequence of the questionnaire. The questions in the questionnaire were ordered in a logical order from the respondents' perceptions. The best way to sequence the question was to start off with more general questions to engage the respondent and then more mixed questions so that the research objectives would not be detected.

The design of the physical questionnaire/ survey plays a vital role in the overall design and affects the rate of response. It is important for the questionnaire to be of good quality to attract the response from the respondent [29]. Due to this, serious consideration was taken when producing the questionnaire, such as its layout, printing and paper quality and clarity of letters. The questionnaire questions were also designed in simple language, allowing respondents to choose from five possible answers. The questions were measured using a five-point Likert scale ranging from 'Excellent' to 'poor', ' highly satisfied' to highly dissatisfied', 'Always' to 'Never', 'strongly agree' to 'strongly disagree' and 'very large extent' to 'very small extent' adopted from [30].

\subsection{Questionnaire Analysis}

Quantitative research usually generates large amount of data, especially the semi-structured interviews. The authors further stated that it is very essential to acknowledge that irrespective of the kind of research (either qualitative or quantitative) a degree of subjectivity does exist. Descriptive information just like some of the data obtained during the collection of results in the research study first goes through a process called content analysis.

For the purpose of this research a process of content analysis was used to evaluate the data collected during the interview session. Content analysis is the process whereby the key themes are identified, those ones that emerge from the descriptions given by respondents or answer to the question. Content analysis is advantageous when presenting the outcomes of open-ended review questions as well as multiple interviews. Content analysis entails code groups of words that are found in transcripts of interviews which are further characterized into sections [31]. It can be added that these groups are commonly reliant on the type of research topic. 


\section{Results and Discussions}

The following presents the results and discussions from the survey and case study within the research.

\subsection{Lean Production Practices Utilised by Company $\mathrm{X}$}

Analysis and findings from Figure (2) demonstrates that $73.3 \%$ of respondents indicated they use VSM and JIT always while $73.3 \%$ of respondent frequently use $5 \mathrm{~S}$ which matched to what [33] stated in their research that JIT, VSM and 5S are used by organisation to improve their operational performance. Other Lean production tools which are being used by organisation even though they are not being used frequently include TPM, Kaizen, Pokayoke, Jidoka and Kanban.

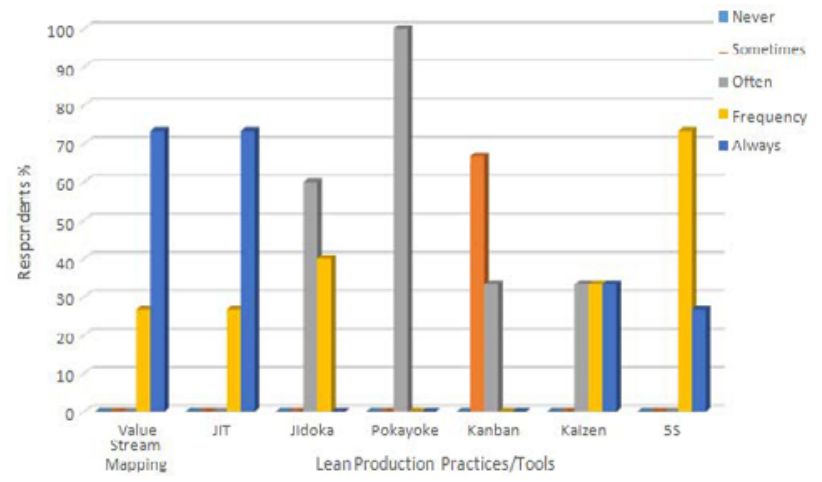

Fig. 2. Lean Production Practices/Tools.

\subsection{Impact of Lean Production Practices on Performance}

Respondents were asked the attributes of Lean production practice tools such as VSM, JIT, 5S, Kaizen, Pokayoke, Jidoka and Kanban in their organisations. These questions corresponded to the indicators within the framework. Below are the findings for one of the tools.

\section{VSM}

Table 2 below shows the results of the frequency analysis for VSM. It is also used to design, map out or analyse all action and has positive impact on the performance of organisation. Based on this, the question was asked "what waste do Lean production practice eradicate in your organisation".

Table 2. Frequency Analysis for Criterion VSM.

\begin{tabular}{|c|c|c|c|c|c|c|c|}
\hline Factor & VSMI & $\begin{array}{l}\text { Strongly } \\
\text { agree }\end{array}$ & Agree & Undecided & Disagree & $\begin{array}{l}\text { Strongly } \\
\text { disagree }\end{array}$ & Mean \\
\hline \multirow{5}{*}{$\begin{array}{l}\text { Quality, speed, } \\
\text { dependability, } \\
\text { flexibility and cost }\end{array}$} & Wastereduction & $40 \%$ & $60 \%$ & $0 \%$ & $0 \%$ & $0 \%$ & 4.40 \\
\hline & $\begin{array}{l}\text { Reduced } \\
\text { production time }\end{array}$ & $40 \%$ & $60 \%$ & $0 \%$ & $0 \%$ & $0 \%$ & 4.40 \\
\hline & Reduced lead time & $26.7 \%$ & $73.3 \%$ & $0 \%$ & $0 \%$ & $0 \%$ & 4.27 \\
\hline & $\begin{array}{l}\text { Enhanced quality } \\
\text { of output }\end{array}$ & $26.7 \%$ & $73.3 \%$ & $0 \%$ & $0 \%$ & $0 \%$ & 4.27 \\
\hline & $\begin{array}{l}\text { Production } \\
\text { smoothing }\end{array}$ & $66.7 \%$ & $0 \%$ & $33.3 \%$ & $0 \%$ & $0 \%$ & 4.33 \\
\hline \multicolumn{2}{|l|}{ Average } & $40 \%$ & $53.32 \%$ & $33.3 \%$ & $0 \%$ & $0 \%$ & 4.33 \\
\hline \multicolumn{7}{|l|}{$\begin{array}{l}\text { Mean } \\
(\max 5.0)\end{array}$} & $86.66 \%$ \\
\hline
\end{tabular}

The mean from respondent answers was approximately $86.6 \%$ indicating that the contribution of the criterion is high. $40 \%$ of the respondents answered with "strongly agree", while 53.32\% answered with "agree" and 33.3\% with "undecided". None of respondents answered with "strongly disagree" or "disagree" in the question. This indicates that respondents believe VSM has positive impact on their performance similar to earlier research studies identified within the literature [23, 32].

\subsection{Adoption of Lean Production Practices in Company $\mathrm{X}$}

Respondents were asked the extent in which the implementation of Lean production practice has impacted on their organisations performance.

Table 3. Frequency Analysis of Adoption of Lean Production Practices in company X.

\begin{tabular}{|l|c|c|c|c|c|c|}
\hline $\begin{array}{l}\text { To what extent has the Implementation } \\
\text { of Lean production practice impacted } \\
\text { on your organisations performance }\end{array}$ & $\begin{array}{c}\text { Very } \\
\text { large } \\
\text { ettent }\end{array}$ & $\begin{array}{c}\text { Large } \\
\text { extent }\end{array}$ & $\begin{array}{c}\text { Moderate } \\
\text { eviat }\end{array}$ & $\begin{array}{c}\text { Small } \\
\text { extent }\end{array}$ & $\begin{array}{c}\text { Very } \\
\text { small } \\
\text { extent }\end{array}$ & Mean \\
\hline Work in process reduction & $6.7 \%$ & $46.7 \%$ & $46.7 \%$ & $0 \%$ & $0 \%$ & 3.60 \\
\hline Inventory reduction & $0 \%$ & $40 \%$ & $53.3 \%$ & $6.7 \%$ & $0 \%$ & 3.33 \\
\hline Lead time reduction & $20 \%$ & $40 \%$ & $26.7 \%$ & $13.3 \%$ & $0 \%$ & 3.67 \\
\hline $\begin{array}{l}\text { Product and service quality } \\
\text { improvement }\end{array}$ & $20 \%$ & $60.7 \%$ & $13.3 \%$ & $0 \%$ & $0 \%$ & 4.07 \\
\hline $\begin{array}{l}\text { Improve material flow and through } \\
\text { put }\end{array}$ & $20 \%$ & $53.3 \%$ & $26.7 \%$ & $0 \%$ & $0 \%$ & 3.93 \\
\hline Waste reduction & $0 \%$ & $40 \%$ & $60 \%$ & $0 \%$ & $0 \%$ & 3.40 \\
\hline Manufacturing cost reduction & $0 \%$ & $40 \%$ & $53.3 \%$ & $6.7 \%$ & $0 \%$ & 3.33 \\
\hline Set up time reduction & $0 \%$ & $33.3 \%$ & $60 \%$ & $6.7 \%$ & $0 \%$ & 3.27 \\
\hline Profitability improvement & $26.7 \%$ & $60 \%$ & $13.3 \%$ & $0 \%$ & $0 \%$ & 4.13 \\
\hline Sales volume improvement & $0 \%$ & $26.7 \%$ & $60 \%$ & $13.3 \%$ & $0 \%$ & 3.13 \\
\hline Labour requirement reduction & $6.7 \%$ & $40 \%$ & $46.7 \%$ & $6.7 \%$ & $0 \%$ & 3.47 \\
\hline Productivity improvement & $20 \%$ & $66 \%$ & $20 \%$ & $0 \%$ & $0 \%$ & 4 \\
\hline \multicolumn{1}{|c|}{ Average } & $10.01 \%$ & $45.56 \%$ & $40 \%$ & 4.45 & $0 \%$ & 3.61 \\
& & & & & & \\
\hline \multicolumn{1}{|c|}{ Mean (max 5.0) } & & & & & $72.2 \%$ \\
\hline
\end{tabular}

Table 3 above summarises the extent in which Lean production practices have been adopted by Company $\mathrm{x}$. From the results, it is clear that the mean is $72.2 \%$ (high). Majority of respondents (mean $=4.13$ ) indicated that profitability improvement has significant impact on implementing Lean production practice. Again, high number of respondent $($ mean $=4.07)$ believes that product and service quality improvement has significant impact on implementing Lean production practice. Again, the responses for Lead time reduction, Work in process reduction, Improve material flow and through put are all high indicating they have significant impact on implementing Lean production practice. However, Inventory reduction, Manufacturing cost reduction, Set up time reduction, Sales volume improvement, Labour requirement reduction are average indicating they have significant impact on implementing Lean production practice in moderate extent.

\subsection{Challenges of Implementing Lean Practices}

Respondents were asked the challenges they faced while implementing Lean practices. Table 4 shows the results of the finding. Table 4 summarises the challenges faced by company $\mathrm{X}$ while implementing Lean practices. From the 
results, it is clear that the mean $(\max 5.0)$ is high. This is because organisation experience lack of top management commitment, lack of continuous education and training, poor information/ data accuracy, employee's resistance to change, and governmental policy. The outcome for financial constraints, inexperienced technical staff, Lack of interface with existing system and solely depending on traditional system of work (between 2.5 to 3.49 ) is average.

Table 4. Frequency Analysis of Adoption of Difficulties for Implementing Lean Practices.

\begin{tabular}{|l|c|c|c|c|c|c|}
\hline $\begin{array}{l}\text { What challenges do Your } \\
\text { organisation face while } \\
\text { implementing Lean practices }\end{array}$ & $\begin{array}{c}\text { Strongly } \\
\text { Aqree }\end{array}$ & Agree & Undecided & Disagree & $\begin{array}{c}\text { Strongly } \\
\text { Disapree }\end{array}$ & Mean \\
\hline $\begin{array}{l}\text { Lack of top management } \\
\text { commitment }\end{array}$ & $33.3 \%$ & $66.7 \%$ & $0 \%$ & $0 \%$ & $0 \%$ & $4.33 \%$ \\
\hline $\begin{array}{l}\text { Lack of continuous } \\
\text { education/ training }\end{array}$ & $33.3 \%$ & $66.7 \%$ & $0 \%$ & $0 \%$ & $0 \%$ & $4.33 \%$ \\
\hline $\begin{array}{l}\text { Poor information/ data } \\
\text { accuracy }\end{array}$ & $33.3 \%$ & $40 \%$ & $26.7 \%$ & $0 \%$ & $0 \%$ & $4.07 \%$ \\
\hline $\begin{array}{l}\text { Solely depending on } \\
\text { traditional system of work }\end{array}$ & $40 \%$ & $26.7 \%$ & $33.3 \%$ & $0 \%$ & $0 \%$ & $3.47 \%$ \\
\hline Financial constraints & $40 \%$ & $0 \%$ & $60 \%$ & $0 \%$ & $0 \%$ & $3.20 \%$ \\
\hline Inexperienced technical staff & $0 \%$ & $60 \%$ & $0 \%$ & $40 \%$ & $0 \%$ & $3.20 \%$ \\
\hline $\begin{array}{l}\text { Lack of interface with } \\
\text { existing system }\end{array}$ & $13 \%$ & $13 \%$ & $40 \%$ & $33.3 \%$ & $0 \%$ & $3.07 \%$ \\
\hline Government policy & $46.7 \%$ & $20 \%$ & $6.7 \%$ & $26.7 \%$ & $0 \%$ & $3.87 \%$ \\
\hline $\begin{array}{l}\text { Employees resistance to } \\
\text { change }\end{array}$ & $46.7 \%$ & $13.3 \%$ & $26.7 \%$ & $13.3 \%$ & $0 \%$ & $3.93 \%$ \\
\hline \multicolumn{1}{|c|}{ Average } & $31.81 \%$ & $34.04 \%$ & $21.49 \%$ & $12.59 \%$ & & 3.72 \\
\hline Mean (max 5.0) & & & & & $74.4 \%$ \\
\hline
\end{tabular}

\section{Conclusions and Future Research}

This research sought to explore Lean production practice on Organisation (Company X) performance. It looked at the impact of Lean production practice on organisation performance, the extent in which lean production practices have been adopted by organisation and the challenges faced by them within their pursuit to implement lean production practices. The study followed a descriptive research design using a questionnaire as the main research tool. The main data was gathered from Company $\mathrm{X}$ although; questionnaire and interview were given to local university students (customers) and university cafe manager respectively. The collected data was analysed using SPSS and Excel tools. An analysis of the results seems to suggest that the most popular Lean production tools used frequently by Company $\mathrm{X}$ are JIT, VSM, 5S and Pokayoke (automation). Furthermore, it can be concluded that JIT has a high impact on improving the overall performance (Quality, Speed, Dependability, Flexibility and Cost) of Company X. Pokayoke also plays a vital role on performance as it helps them to prevent and eliminate quality defect especially on speed, quality, dependability and cost, while Kaizen and 5S have a moderate impact on their overall performance (Quality and Speed).

Lean production practice also helped company $\mathrm{X}$ to deliver their products and service faster and cheaper thus reducing inventory. However, when implementing lean, most of company $\mathrm{X}$ are still missing out value creating activities toward their final customers. Company $\mathrm{X}$ still faces challenges such as lack of top management commitment, lack of continuous education/ training, governmental reforms and policies, financial constraints and employee participations when implementing lean practices. Hence, the important elements of cost-deliveryflexibility-value can be achieved through constant training, education, teamwork and desire to change. Based on the survey given to students who purchased baked goods on campus, it was seen that students were not $100 \%$ satisfied with baked goods that were available on campus. Again, from the interview conducted from cafe outlet, it was seen that before they choose their suppliers, they consider quality-product varieties, delivery time, price and consistency. These are the most decisive factors in considering a supplier, and the café outlet tends to remain with the same supplier for better customer satisfaction. This implies that the cafe always needs their supplies to be delivered with efficiency and effectively. This can be achieved with further adoption of lean production practices.

Lean production is a considered as continuous process; however, for Company $\mathrm{X}$ to boost their production and remain competitive in present market, they must understand their customers need and design ways on fulfilling their requirements and expectations. All waste including activities which consume resources, time, space and non-value added product or service should be eliminated. Total cost waste such as over-production which increases the inventory costs due to the storage needs should also be eliminated. Again, time waste such as time taken to start and finish the required product should be reduced. Company $\mathrm{C}$ should always avoid overproduction since it is a major factor towards waste. Again, since lean production is based mainly on JIT production, therefore, in all the production process, only required amount of produce depending upon the demand and the order should be produced. There should be a good relationship between the customers and suppliers. Organisations should ensure that before lean production is implemented, the entire workforce are properly informed and trained appropriately. This will enable the proper utilisation of knowledge delivery and the skills required to adopt the practices more effectively within the environment. All respective departments and business units within the business need to properly understand their roles and application of lean transformation process. Hence, more resources should be allocated towards future growth and implementation of the change management and adoption of lean production practices within the company.

\section{References}

[1] J. Womack., D. Jones, Lean Thinking: Banish Waste and Create Wealth in Your Corporation. Simon \& Schuster, New York, USA (1996)

[2] A. Henderson, L. Larco, Lean Transformation: How to Change Your Business into a Lean Enterprise, Richmond, VA: The Oaklea Press (1999)

[3] J. Bicheno, The New Lean Toolbox, $5^{\text {th }}$ Ed, Piscie, Publishers, ISBN: 0956830757, (2016) 
[4] L. Emiliani, Linking leader's beliefs to their behaviours and competencies, Management Decision, 41 (9), 2-6 (2006)

[5] P. Womack, D. Jones, D. Roos, The machine that changed the World: The triumph of lean production, Simon \& Schuster UK, ISBN: 1847370551, (2007)

[6] S. Spear. The Toyota Production System: An example of managing complex social/technical systems, Ph.D. dissertation, Harvard Business School, Boston, MA, (1999)

[7] S. Pavnaskar, J. Gershenson, A. Jambekar, Classification Scheme for Lean Manufacturing Tools, Int. J. Prod Res, 41 (13), 3075-3090 (2003)

[8] H. HosseiniNasab, T. Aliheidari, H. KhademiZare, Finding a probabilistic approach to analyse lean manufacturing, J Clean Prod, 29, 73-81 (2012)

[9] M.A. Lewis, Lean production and sustainable competitive advantage, Int J Oper Prod Man, 20 (8), 959-978, (2000)

[10] P. Hine, M. Holweg, N. Rich, Learning to evolve: A review of contemporary lean thinking, Int J Oper Prod Man, 24 (10), 994-1011 (2004)

[11] R. Shah, P. Ward, Defining and developing measures of Lean production, J. Oper. Manag, 25 (4), 785-805 (2007)

[12] RJ. Boaden. What is total quality management...And does it matter?, Total Quality Management, 8 (4), 153-71 (1997)

[13] R. Anderson, H. Eriksson, H. Torstenson, Similarities and differences between TQM, six sigma and Lean, The TQM Magazine, 18 (3), 282-296 (2006)

[14] S. Parker, Longitudinal effects of Lean production on employee outcomes and the mediating role of work characteristics, J. Appl. Psychol. 88 (4), 620-34 (2003)

[15] J. Pettersen, Defining lean production: some conceptual and practical issues, The TQM Journal, 21 (2), 127-142 (2009)

[16] P. Forrester, U. Shimizu, H. Soriano-Meier, J. GarzaReyes, and L. Basso, Lean Production, Market Share and Value Creation in the Agricultural Machinery Sector in Brazil, JMTM, 21 (7), 853-871 (2010)

[17] E. Bayou, A. Korvin, Measuring the Leanness of Manufacturing Systems - A Case Study of Ford Motor Company and General Motors, J Eng Technol Manage, 25 (4), 287-304, (2008)

[18] A. Anvari, N. Zulkifli, R. Yusuff, A Dynamic Modeling to Measure Lean Performance within Lean Attributes, Int J Adv Manuf Techno, 66 (5), 663-677 (2013)

[19] S. Vinodh, K. Vimal, Thirty Criteria Based Leanness Assessment Using Fuzzy Logic Approach, Int J Adv Manuf Techno, 60 (9), 1185-1195 (2012)

[20] S. Bhasin, Lean and performance measurement, Journal of Manufacturing Technology Management. 19 (5), 670-684 (2008)

[21] R. Kaplan, D.P. Norton, The office of strategic management, Strategic Finance, 87, 56-60 (2005)

[22] S. Bhasin. Performance of Lean in Large Organisations, Journal of Manufacturing Systems, 31 (3), 349-357 (2012)

[23] W. Goriwondo, S. Mhlanga, A. Marecha, Use of the Value Stream Mapping Tool for Waste Reduction in Manufacturing. Case Study for Bread Manufacturing In Zimbabwe, In Procedia 2011 I. C. Industrial Engineering and Operations Management, 1 (1), 236-241 (2011)

[24] J. Womack, D. Jones, Lean Thinking: Banish Waste and Create Wealth in Your Corporation, Free Press, ISBN: 0743231643, (2003)

[25] M. Dudek-Burlikowska, D. Szewieczek, The Poka-Yoke method as an improving quality tool of operations in the process, J. Achiev. Mater. Manuf. 36 (1), 95-102 (2009)

[26] Y. Sugimori, K. Kusunoki, F. Cho, S. Uchikawa, Toyota production system and Kanban system Materialization of just-in-time and respect-for-human system, Int. J Prod Res, 15 (6), 553 -564 (1977)

[27] H. Maylor, K. Blackmon. Research Business and Management, Palgrave Publishers, ISBN: 0333964071 (2005)

[28] N. Malhotra., D. Birks, Marketing Research: Applied Approach, Pearson Publishers, ISBN: 0273725855, (2012)

[29] E. Fanning, Formatting a paper-based survey questionnaire: Best practices, Practical Assessment Research \& Evaluation, 10 (12) (2005)

[30] R. Sanchez, V. Cortijo, U. Javed, Students' perceptions on Facebook for academic purposes, Computers \& Education, 70, 138-149 (2014)

[31] D. Carson, A. Dilmore., C. Perry., K. Gronhaug. Qualitative Marketing Research, Sage Publishers, ISBN: 0761963669, (2009)

[32] L. Rocha-Lona, J. Garza-Reyes, V. Kumar, Building Quality Management Systems: Selecting the Right Methods and Tools, CRC Press, Taylor \& Francis, ISSN: 9781466564992, (2013)

[33] I. Belekoukias, A. Jose, K. Vikas, The Impact of Lean Methods and Tools on the Operational Performance of Manufacturing Organisations, Int. J Prod Res, 52 (18) 5346-5366 (2014) 